\title{
Pathogenicity of Philippine and Indonesian Trypanosoma evansi Isolates in Mice and Their Responses to Trypanocides
}

\author{
Dargantes $\mathrm{AP}^{1,2}$, Wardhana $\mathrm{AH}^{3,4}$, Abella $\mathrm{JAC}^{1}$, Sequito $\mathrm{MR}^{1}$, Reid $\mathrm{SA}^{2}$, Copeman $\mathrm{DB}^{5}$ (deceased), Dargantes $\mathrm{KAT}^{1}$ \\ ${ }^{1}$ College of Veterinary Medicine, Central Mindanao University, Musuan 8710, Bukidnon, Philippines \\ ${ }^{2}$ School of Veterinary and Biomedical Sciences, Murdoch University, South Street, Murdoch, \\ Western Australia 6150, Australia \\ ${ }^{3}$ Department of Parasitology, Indonesian Research Centre for Veterinary Science (IRCVS), Bogor 16114, Indonesia \\ ${ }^{4}$ Department of Veterinary Parasitology, Faculty of Veterinary Medicine, Airlangga Univdersity, Surabaya, 60115, Indonesia \\ ${ }^{5}$ Australian Institute of Tropical Veterinary and Animal Science, James Cook University, Townsville 4811, Queensland, Australia \\ E-mail: alanpdargantes@gmail.com
}

(received 15-05-2020; revised 18-01-2021; accepted 22-01-2021)

\begin{abstract}
ABSTRAK
Dargantes AP, Wardhana AH, Abella JAC, Sequito MR, Reid SA, Copeman DB, Dargantes KAT. 2020. Patogenitas isolat Trypanosoma evansi asal Philippina dan Indonesia pada mencit serta responnya terhadap trypanosidal. JITV 26(1): 22-30. DOI: http://dx.doi.org/10.14334.jitv.v26i1.2508.

Patogenitas sepuluh isolat Trypanosoma evansi asal Filipina (Mindanao) dan satu isolat asal Indonesia (Jawa Timur) dipelajari dan dibandingkan. Disamping itu, studi ini juga menguji kepekaan isolat-isolat tersebut terhadap beberapa trypanosidal, yaitu diminazene aceturate, melarsomine dihydrochloride, suramin and quinapyramine sulphate/chloride. Sebanyak 25 mencit diinfeksi secara interperitoneal dengan masing-masing isolat dan 20 mencit diberi perlakuan dengan 4 obat (5 mencit/obat), sementara itu kelompok yang lain terdiri dari 5 ekor per isolat sebagai kelompok kontrol diinfeksi tanpa pengobatan dan 7 ekor per isolat sebagai kelompok yang tidak diinfeksi. Pengobatan dilakukan pada 24 jam pasca infeksi dan parasitemia diamati setiap hari selama 35 hari. Mencit yang diinfeksi dengan isolat Filipina secara nyata mengalami kematian lebih awal (hari ke 5 -11) dibandingkan dengan isolat Indonesia (hari ke 14 -16). Periode prepaten isolat Filipina juga secara nyata lebih pendek ( $3-8$ hari) daripada isolat Indonesia (11 - 13 hari). Trypanosoma tidak terdeteksi di dalam darah mencit yang diinfeksi isolat Filipina setelah diobati dengan quinapyramine sulphate/chloride, melarsomine dihydrochloride atau suramin. Dua dari sepuluh isolat baik yang diinfeksi dengan isolat Filipina (C4 atau A9) yang kemudian diobati dengan diminazene aceturate masih menunjukkan parasitemia pada hari 29 dan 31. Disimpulkan bahwa isolat T. evansi dari Mindanao, Filipina lebih patogen dibandingkan dengan isolat dari Jawa Timur, Indonesia. Quinapyramine sulphate/chloride, melarsomine dihydrochloride dan suramin efektif terhadap T. evansi yang diteliti. Informasi ini sangat penting untuk meningkatkan strategi pengendalian Surra di Filipina dan Indonesia.
\end{abstract}

Kata Kunci: Jawa Timur, Mindanao, Patogenitas, Resisten, Trypanosoma evansi

\section{ABSTRACT}

Dargantes AP, Wardhana AH, Abella JAC, Sequito MR, Reid SA, Copeman DB, Dargantes KAT. 2020. Pathogenicity of Philippine and Indonesian Trypanosoma evansi isolates in mice and their responses to trypanocides. JITV 26(1): 22-30. DOI: http://dx.doi.org/10.14334.jitv.v26i1.2508.

Pathogenicity of 10 isolates of T. evansi collected from Mindanao, Philippines, and one isolate from East Java, Indonesia was determined and compared. The susceptibility of these isolates against diminazene aceturate, melarsomine dihydrochloride, suramin and quinapyramine sulphate/chloride was also tested. Twenty-five mice were infected intraperitoneally with each isolate and 20 were treated with the 4 drugs ( 5 mice/drug) while 5 infected and 7 uninfected mice served as infecteduntreated and uninfected controls, respectively. Treatment was carried out 24 hours post-infection and parasitemia was monitored for 35 days. Mice infected with Philippine isolates significantly died earlier (5-11 days) than those infected with the Indonesian isolate (14-16 days). The prepatent period for Philippine isolates (3-8 days) was significantly shorter than the Indonesian strain (11-13 days). Trypanosomes were not observed in the blood of mice infected with any of the Philippine isolates when treated with quinapyramine sulphate/chloride, melarsomine dihydrochloride or suramin. Two of 10 mice infected with either C4 or A9 Philippine isolates and treated with diminazene aceturate had parasitemia on days 29 and 31, respectively. It is concluded that isolates of T. evansi from Mindanao, Philippines, are more pathogenic than the isolate from East Java, Indonesia. This study also indicated that quinapyramine sulphate/chloride, melarsomine dihydrochloride and suramin are effective against these T. evansi isolates from Mindanao, Philippines and East Java, Indonesia, while two of the Mindanao isolates are resistant to diminazene. This information is valuable in the enhancement of the control strategy against surra in the Philippines and Indonesia.

Key Words: East Java, Mindanao, Pathogenicity, Resistance, Trypanosoma evansi 


\section{INTRODUCTION}

Trypanosomosis (Surra) caused by a protozoan parasite, Trypanosoma evansi, remains a major problem in livestock and wild animals. The parasite is widely distributed in Central and South America, Africa and South-east Asia including the Philippines and Indonesia (Boushaki et al. 2019). In some countries, the parasite has been also reported to infect humans (zoonotic) (Desquesnes et al. 2013; Chau et al. 2016; Wardhana \& Sawitri 2018). Dewi et al. (2020) reported that the economic losses of surra outbreak in East Sumba of Indonesia were 25.7 billion rupiahs during 3 years (2010 - 2012) while in Mindanao, Philippines, a village with moderate to high surra in its livestock loses about US\$158,000 annually (2.3 billion rupiahs) (Dobson et al. 2009).

Severe outbreaks of surra in the Philippines were reported in South Cotabato and Agusan del Sur, Mindanao between 1989-1994 (McInnes et al. 2012). The disease spread to other provinces in the following years. The strain of $T$. evansi causing the outbreaks was suspected to be highly virulent, previously not present in the country (Lazaro et al. 2019). In Indonesia, $T$. evansi was first identified from an outbreak of the disease amongst horses in Semarang in 1897 (Nuryady et al. 2019). Furthermore, some outbreaks occurred subsequently in cattle and water buffaloes in East Java, then surra rapidly spread to other islands in Indonesia (Dewi et al. 2019; Sawitri et al. 2019). The parasite can easily spread between provinces through infected water buffaloes, horses and cattle brought by transmigrating people or dispersed by the government as part of its animal dispersal project (Dargantes et al. 2009; Desquesnes et al. 2013; Sawitri et al. 2019).

Mekonnen et al. (2018) stated that control of surra normally relies on drug treatment and vector control, including chemoprophylaxis. The common drugs used for surra treatment are suramin, diminazene aceturate, quinapyramine and melarsomine (Gressler et al. 2015; Shiferaw et al. 2015; Gillingwater 2018). However, only two drugs, isometamidium and diminazene aceturate, are officially marketed in Indonesia (Dewi et al. 2019; Dewi et al. 2020).

Differences in pathogenicity and drug sensitivity amongst isolates of $T$. evansi have been documented elsewhere but not in Mindanao (Jatau et al. 2010; Kamidi et al. 2018). Gressler et al. (2015) stated that the pathogenicity of $T$. evansi may vary depending on the strain, host species and some non-specific factors such as stress, concurrent infections, or epizootiological local conditions.

During the past decade, several outbreaks of surra have occurred in Mindanao, Philippines, that caused high morbidity and mortality in horses, buffaloes, cattle and small ruminants. This pattern seems to be different from that described in the neighboring Indonesian archipelago where outbreaks only occur sporadically and are often localized. This raises the suspicion that strains of the parasite with different levels of pathogenicity may be present in Mindanao.
The present study was undertaken to provide some of this information. The pathogenicity of 10 isolates of T. evansi collected from animals in different areas in Mindanao, Philippines, and one isolate from East Java, Indonesia was determined and compared. In addition, efficacy of four different trypanocides was also tested. The information generated from this endeavor is valuable for the enhancement of the control strategy against surra in Mindanao, Philippines and Indonesia.

\section{MATERIAL AND METHODS}

\section{Study site and ethical approval}

The laboratory trial was done at the Animal Disease Diagnostic Laboratory of the College of Veterinary Medicine, Central Mindanao University, Philippines, with approval of the research protocol by the Animal Ethics Subcommittee of James Cook University, Australia (Permit no. A779-02; 2003).

\section{Isolates of $T$. evansi}

The origin of Philippine and East Javanese isolates of $T$. evansi used in this study are presented in Table 1 . All isolates were passaged in mice twice then maintained in guinea pigs until tested.

\section{Preparation of the inoculum}

The inoculum for each isolate was prepared from the blood of an infected mouse. After counting the parasite in the blood, when parasitemia was high, a drop of tail blood was diluted with phosphate-buffered saline glucose (PBSG; $\mathrm{pH}=8.0$ ) and viable trypanosomes were counted using a Neubauer hemocytometer. Blood was then diluted with PBSG to provide $15 \mathrm{~mL}$ of inoculum with 5,000 trypanosomes per $\mathrm{mL}$ (Sawitri \& Wardhana 2017).

\section{Infection of laboratory mice}

A total of 352, 6-9 week-old DDY mice each weighing an average of $20 \mathrm{~g}$ were used in the trial. The mice were purchased from a local colony and examined to ensure freedom from blood parasites prior to infection. They were acclimatized for two weeks before the trial (Sawitri \& Wardhana 2017).

For each isolate, 32 mice were randomly selected, 25 of which were each infected intraperitoneally (ip) with $0.2 \mathrm{~mL}$ of inoculum containing 1,000 T. evansi. For the infected mice, 4 groups of 5 were treated with 4 trypanocides and one group of 5 served as untreated, infected controls. The seven uninfected mice served as untreated uninfected controls for each isolate. The trial was carried out in three batches.

The selected mice were housed in plastic cages separated according to isolates, and provided with clean 
Dargantes et al. Pathogenicity of Philippine and Indonesian Trypanosoma evansi isolates in mice and their responses to trypanocides

Table 1. Origin and dates of collection of 11 isolates stock of T. evansi used in the present study

\begin{tabular}{llll}
\hline \hline \multirow{2}{*}{ Code } & \multicolumn{1}{c}{ Species } & \multicolumn{1}{c}{ Origin } & $\begin{array}{c}\text { Collection } \\
\text { Date of the Stock }\end{array}$ \\
\cline { 2 - 4 } & Horse & Cacub, Marbel, South Cotabato, Mindanao, Phl & 15 January 2002 \\
C1 & Buffalo & Cacub, Marbel, South Cotabato, Mindanao, Phl & 15 January 2002 \\
C3 & Buffalo & Cacub, Marbel, South Cotabato, Mindanao, Phl & 16 January 2002 \\
C4 & Buffalo & Cacub, Marbel, South Cotabato, Mindanao, Phl & 16 January 2002 \\
C5 & Buffalo & Cacub, Marbel, South Cotabato, Mindanao, Phl & 16 January 2002 \\
A8 & Buffalo & Sta. Josefa, Agusan del Sur, Mindanao, Phl & 16 January 2002 \\
A9 & Buffalo & Talacogon, Agusan del Sur, Mindanao, Phl & 15 January 2002 \\
A10 & Buffalo & Talacogon, Agusan del Sur, Mindanao, Phl & 15 January 2002 \\
A11 & Buffalo & Talacogon, Agusan del Sur, Mindanao, Phl & 15 January 2002 \\
A13 & Buffalo & Veruela, Agusan del Sur, Mindanao, Phl & 16 January 2002 \\
EJ1 & Buffalo & Tuban, East Java, Indonesia & 5 September 1984 \\
\hline
\end{tabular}

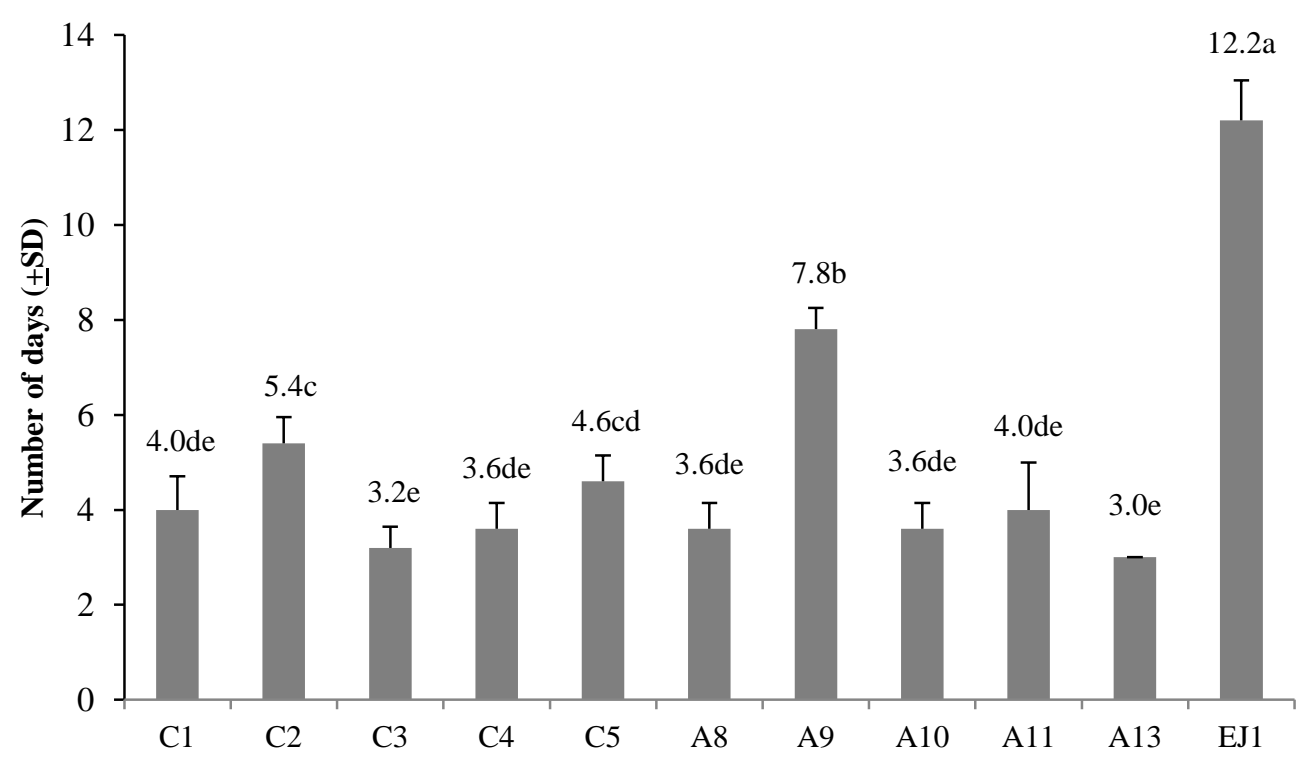

T. evansi isolates

Figure 1. Mean pre-patent periods (days $\pm \mathrm{SD}$ ) of 10 Philippine isolates (C1-A13) and an Indonesian isolate (EJ1) of T. evansi in mice. Means with different letters are significantly different $(p<0.05)$.

water and commercial pelletized feed, ad libitum. The cages were arranged in an open metal cabinet in a wellventilated room. The litter material of sterile wood shavings was changed every 4 days during the trial.

\section{Treatment with trypanocides}

Four trypanocides were tested against $T$. evansi infection in mice using the following dose regimens: diminazene aceturate (Berenil ${ }^{\circledR}$, Hoechst, Germany) ip at $7 \mathrm{mg} \mathrm{kg}^{-1}$ bw; melarsomine dihydrochloride
(Immiticide ${ }^{\circledR}$, A Webster, NSW, Australia) ip at $2 \mathrm{mg}$ $\mathrm{kg}^{-1}$ bw; suramin (Naganol ${ }^{\circledR}$, Bayer, Germany) ip at 10 $\mathrm{mg} \mathrm{kg}{ }^{-1} \mathrm{bw}$; and quinapyramine sulphate/chloride (Triquin $^{\mathrm{TM}}$, Sanjivani Paranteral Limited, India) subcutaneously at $5 \mathrm{mg} \mathrm{kg}^{-1} \mathrm{bw}$. The drugs were diluted separately with sterile distilled water to a working concentration of 1-2 mg mL $\mathrm{m}^{-1}$ and refrigerated (not more than 48 hours) until used. Each mouse was weighed using a digital weighing scale (Mettler, USA) and the amount of drug was calculated based on the dose regimen. Treatment was administered 24 hours after infection. 


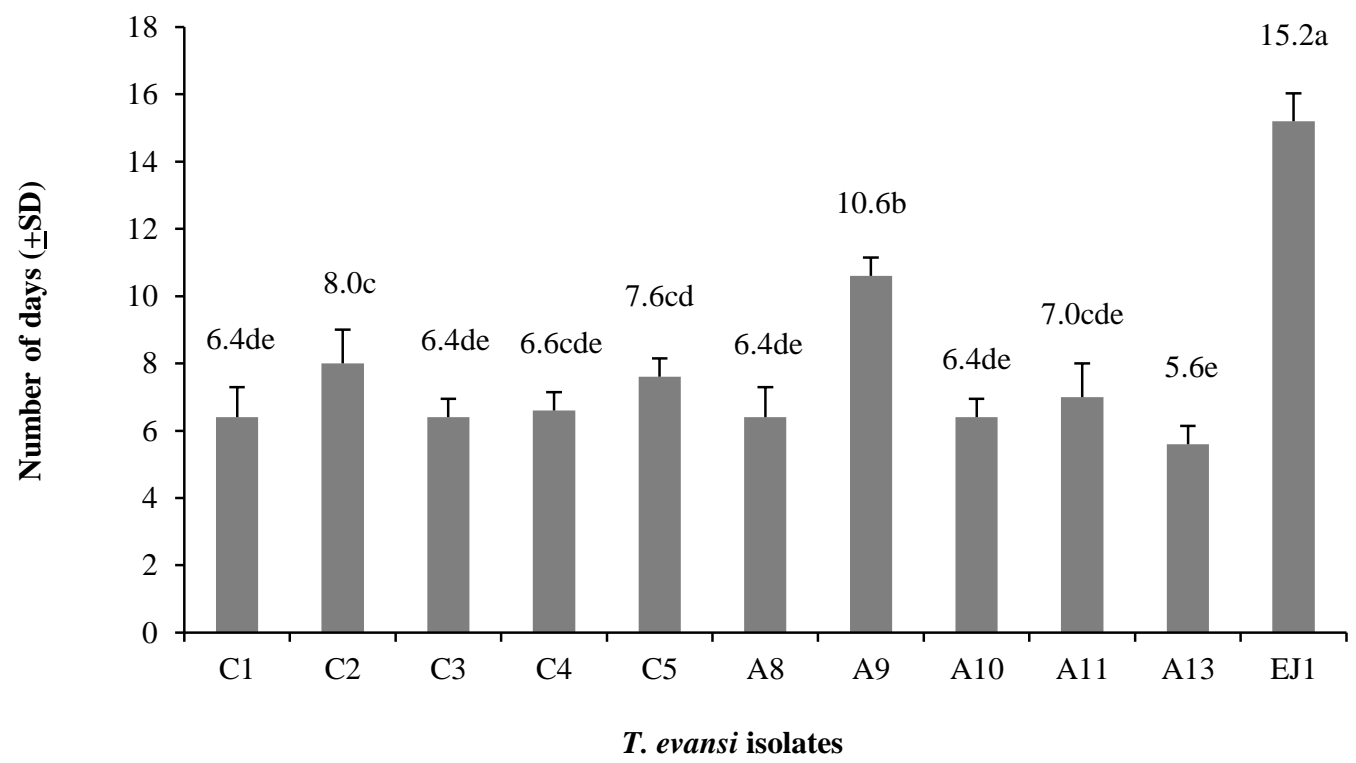

Figure 2. Mean duration of survival (days \pm SD) of mice after infection with 10 Philippine isolates (C1-A13) and an Indonesian (EJ1) isolate of T. evansi. Means with different letters are significantly different $(p<0.05)$.

\section{Monitoring of parasitemia and pathology}

Untreated-infected mice and the uninfected controls were examined daily for presence of trypanosomes in the blood by wet blood film taken from the tail tip (Villareal et al. 2013; Garba et al. 2017). The mice were monitored for clinical signs after infection. Treated mice were similarly monitored every 2 days, for 35 days after treatment. Heart smears were made from each mouse that died and examined for trypanosomes. Necropsy was conducted of every dead mouse and gross lesions were noted.

Pre-patent period and the duration of survival of infected, untreated mice were used as indices of pathogenicity. Absence of parasitemia among treated mice was regarded as an indicator of drug efficacy against T. evansi. Any surviving mouse after being treated using any of the four trypanocides was considered cured (Begolo et al. 2018).

\section{Analyses of data}

The statistical significance of differences $(p<0.05)$ in duration of survival and pre-patent period between groups was determined by one-way analysis of variance (ANOVA) and Tukey's honestly significantly different test (Tukey's HSD) using SPSS statistical program.

\section{RESULTS AND DISCUSSION}

\section{Pathogenicity}

All mice infected with any of the isolates and not treated with a trypanocide developed a disease and died subsequently. The pre-patent period and duration of survival varied significantly $(p<0.05)$ amongst isolates (Figures 1 and 2). Pre-patent period and duration of survival were correlated. Mice infected with Mindanao isolates died earlier (5-11 days) than those infected with the Indonesian isolate (14-16 days) $(p<0.05)$. The prepatent period for the Mindanao isolates varied between 3-8 days and was significantly shorter $(p<0.05)$ than that of the Indonesian strain (11-13 days). Compared to all 10 isolates from Mindanao, the East Javanese isolate had lower pathogenicity. There was also heterogeneity in pathogenicity of the Mindanao isolates but only one (A9) stood out as being significantly different (lower pathogenicity; $p<0.05)$ than the others. Before death, mice showed signs of general weakness and recumbency and appeared to be tilted on one side. Gross lesions observed at necropsy were splenomegaly, hepatomegaly, petechial hemorrhages in the intestines, and congested spleen, kidneys and lungs. No differences in gross lesions between isolates were observed.

This is the first attempt to compare the pathogenicity and drug sensitivity of different isolates of T. evansi from Mindanao, Philippines and an isolate from East Java, Indonesia. All isolates induced a fatal infection in mice. However, pre-patent period and duration of survival were significantly longer with the East Javanese isolate indicating that it is less pathogenic in mice than those taken from Mindanao, Philippines. The present finding on the differences of virulence of $T$. evansi isolates in Mindanao supports the observation of Verdillo et al. (2012) and Mekata et al. (2013) on the varying levels of pathogenicity among $T$. evansi isolates in the Philippines in mice. The pathogenicity of the 10 
Mindanao T. evansi isolates can be considered as moderate to high while that of the East Javanese isolate as low to moderate based on the classification by Sawitri \& Wardhana (2017). Using 25 T. evansi isolates (collected from livestock in various regions in Indonesia) to infect mice and confirmed by molecular tools using ESAG 6/7 gene as marker, Sawitri \& Wardhana (2017) classified the virulence levels of the Indonesian isolates into three, namely: high (death of mice less than 7 days, post-infection, pi), moderate (death of mice between 7-15 days, pi) and low virulence (death of mice more than 15 days, pi).

Regional differences in the pathogenicity of $T$. evansi in mice have been also documented by others. Sawitri \& Wardhana (2017) demonstrated that isolates of $T$. evansi collected from the same region in Indonesia had different levels of virulence in mice. In Pantanal, Brazil, different $T$. evansi isolates collected from domestic and wild animals showed marked heterogeneity in their morphology and pathogenicity in rodents despite demonstrating homogeneity in their biochemical and molecular properties (Parreira et al. 2016). Kamidi et al. (2018) also provided additional evidence regarding regional differences in the virulence of T. evansi.

The various pathogenicity patterns have been also reported among Trypanosoma vivax, T. congolense and T. brucei which are distributed widely among cattle in Africa and Latin America. Ramirez-Barrios et al. (2019) showed that $T$. vivax showed moderate to high pathogenicity in experimentally-infected sheep while varying virulence was observed for $T$. congolense isolates in mice, nude rats, and bovine (Bengaly et al. 2002; Giordani et al. 2016). Likewise, differences in virulence was also detected among $T$. brucei gambiense isolates in Balb/c mice (Holzmuller et al. 2008).

Queiroz et al. (2000) indicated that pathogenicity as measured by survival time after infection could be regarded as a biological marker for the heterogeneity of isolates of $T$. evansi. However, whether heterogeneity in mice is a reflection of similar heterogeneity of pathogenicity in domestic animals is unknown. Furthermore, there is probably sufficient variation in resilience between individual domestic animals and between species that minor differences in pathogenicity of strains in domestic animals in different regions may not be apparent clinically. Such seems to be the case in Mindanao where the isolate, which was significantly less pathogenic in mice than the other isolates from Mindanao, was taken from a buffalo with surra that was not noticeably clinically different from the other cases from which T. evansi isolates were taken.

On the other hand, the lower pathogenicity in mice of the East Javanese isolate as compared to all isolates from Mindanao paralleled the pathogenicity of surra in domestic animals in Indonesia and Mindanao. Thus, the extent to which measurable variations in pathogenicity of different isolates of $T$. evansi in mice reflect a biologically significant difference in domestic animals is still unresolved. Results from this study implied that a two-fold difference in pathogenicity in mice may indicate a similar trend in domestic animals. However, the measurement of minor pathogenicity variation, which is common in mice due to their uniform susceptibility, may result in greater variability between individual domestic animals due to their resilience to $T$. evansi infection.

\section{Drug efficacy}

No trypanosomes was found in the blood of mice infected with any of the T. evansi isolates of Mindanao during the 35-day observation period and treated with quinapyramine sulphate/chloride, melarsomine dihydrochloride or suramin (Table 2). In contrast, two of 10 mice infected with either $\mathrm{C} 4$ or A9 isolates (5 mice each) and treated with diminazene aceturate $\left(\right.$ Berenil ${ }^{\circledR}$ ) had detectable parasitemia (relapsed infection) on days 29 and 31, respectively. Both mice died 5 days after parasites were detected in their blood. On the other hand, parasites were not detected in mice infected with the East Javanese isolate and treated with any of the drugs. All infected, untreated mice developed infection and died subsequently. Trypanosoma evansi infection usually results to $20-100 \%$ fatality in mice (Perrone et al. 2018).

Gillingwater et al. (2009) stated that a dosage of 1 $\mathrm{mg} \mathrm{kg}^{-1}$ bw of quinapyramine administered for 4 consecutive days was able to cure all mice infected with T. evansi of Chinese origin. Another study reported that $50 \%$ of mice infected with $T$. evansi from the same origin were cured after treatment with quinapyramine at a dose rate of $5 \mathrm{mg} \mathrm{kg}^{-1}$ bw (Zhou et al. 2004). However, Macaraeg et al. (2013) revealed that T. evansi isolates from the Philippines were more susceptible to more than $3-10 \mathrm{mg} \mathrm{kg}^{-1}$ bw of quinapyramine. In addition, the authors suggested that $T$. evansi isolates from Luzon island required a higher dose to cure the infection (10 mg kg $\mathrm{mg}^{-1} \mathrm{bw}$ ) compared to $T$. evansi from Visayas and Mindanao islands (3-<10 $\left.\mathrm{mg} \mathrm{kg}^{-1} \mathrm{bw}\right)$. Accordingly, the dosage of quinapyramine used in the present study was slightly higher than that of the previous study (5 mg kg ${ }^{-1} \mathrm{bw}$ ) following the dose regimen recommended by the manufacturer. The fact that all infected mice were cured in this study indicated that the drug is effective for surra.

Melarsomine dihydrochloride, as shown in the present study, is effective against the 10 Philippine and Indonesian T. evansi isolates. This drug is not used in the Philippines and Indonesia for surra thus explains the sensitivity of these isolates to the drug (Dobson et al. 2009; Dewi et al. 2019; Dewi et al. 2020). The drug is also effective to treat experimental surra in buffaloes at 
Table 2. Efficacy of different trypanocides against infection with 10 Mindanao (Philippines) isolates and one East Javanese (Indonesia) isolate of T. evansi in mice

\begin{tabular}{|c|c|c|c|c|c|c|c|}
\hline \multirow[b]{2}{*}{ Code } & \multirow[b]{2}{*}{ Origin } & \multicolumn{6}{|c|}{ Mortality due to T. evansi ; \% Efficacy* } \\
\hline & & $\begin{array}{l}\text { Uninfected- } \\
\text { untreated (7 } \\
\text { mice per } \\
\text { isolate) }\end{array}$ & $\begin{array}{l}\text { Infected- } \\
\text { untreated } \\
\text { (5 mice per } \\
\text { isolate) }\end{array}$ & $\begin{array}{l}\text { Diminazene } \\
\text { aceturate } \\
\left(\text { Berenil }^{\circledR}\right) \\
7 \mathrm{mg} \mathrm{kg}^{-1} \text { bw }\end{array}$ & $\begin{array}{l}\text { Melarsomine } \\
\text { dihydrochloride } \\
\left(\text { Immiticide }^{\circledR}\right) \\
2 \mathrm{mg} \mathrm{kg}^{-1} \text { bw }\end{array}$ & $\begin{array}{l}\text { Quinapyramine } \\
\text { Sulphate/Chloride } \\
\text { (Triquin }^{\mathrm{TM}} \text { ) } \\
5 \mathrm{mg} \mathrm{kg}^{-1} \text { bw }\end{array}$ & $\begin{array}{c}\text { Suramin } \\
\text { (Naganol } \\
\begin{array}{c}\mathrm{Q}^{\prime} \\
\text { ) }\end{array} \\
10 \mathrm{mg} \mathrm{kg}^{-1} \\
\mathrm{bw}\end{array}$ \\
\hline $\mathrm{C} 1$ & Philippines & $0 ;-$ & $5 ;-$ & $0 ; 100$ & $0 ; 100$ & $0 ; 100$ & $0 ; 100$ \\
\hline $\mathrm{C} 2$ & Philippines & $0 ;-$ & $5 ;-$ & $0 ; 100$ & $0 ; 100$ & $0 ; 100$ & $0 ; 100$ \\
\hline $\mathrm{C} 3$ & Philippines & $0 ;-$ & $5 ;-$ & $0 ; 100$ & $0 ; 100$ & $0 ; 100$ & $0 ; 100$ \\
\hline $\mathrm{C} 4$ & Philippines & $0 ;-$ & $5 ;-$ & $1 ; 80 * *$ & $0 ; 100$ & $0 ; 100$ & $0 ; 100$ \\
\hline $\mathrm{C} 5$ & Philippines & $0 ;-$ & $5 ;-$ & $0 ; 100$ & $0 ; 100$ & $0 ; 100$ & $0 ; 100$ \\
\hline A8 & Philippines & $0 ;-$ & $5 ;-$ & $0 ; 100$ & $0 ; 100$ & $0 ; 100$ & $0 ; 100$ \\
\hline A9 & Philippines & $0 ;-$ & $5 ;-$ & $1 ; 80 * * *$ & $0 ; 100$ & $0 ; 100$ & $0 ; 100$ \\
\hline A10 & Philippines & $0 ;-$ & $5 ;-$ & $0 ; 100$ & $0 ; 100$ & $0 ; 100$ & $0 ; 100$ \\
\hline A11 & Philippines & $0 ;-$ & $5 ;-$ & $0 ; 100$ & $0 ; 100$ & $0 ; 100$ & $0 ; 100$ \\
\hline A13 & Philippines & $0 ;-$ & $5 ;-$ & $0 ; 100$ & $0 ; 100$ & $0 ; 100$ & $0 ; 100$ \\
\hline EJ1 & Indonesia & $0 ;-$ & $5 ;-$ & $0 ; 100$ & $0 ; 100$ & $0 ; 100$ & $0 ; 100$ \\
\hline
\end{tabular}

- not applicable, *The number of mice tested for each drug and for each isolate was five, ** Relapsed infection occurred on day 29 , ***Relapsed infection occurred on day 31

$0.5 \mathrm{mg} \mathrm{kg}^{-1}$ bw in Mindanao, Philippines (Dargantes et al. in preparation). However, in Africa where the drug is used to treat surra in camels, melarsomine is no longer effective at $0.125 \mathrm{mg} \mathrm{kg}^{-1}$ bw dose (Kabi et al. 2009). In addition, Hébert et al. (2018) reported that melarsomine is unable to kill $T$. equiperdum in the central nervous system of infected horses and therefore discourages the use of this drug to treat animals suffering from a nervous type of dourine and perhaps of surra.

All infected mice treated with suramin in the present study were cleared of the parasite. Comparable results were reported by Al-Mohammed (2008) and concluded that a dosage of $10 \mathrm{mg} \mathrm{kg}^{-1} \mathrm{bw}$ of suramin is effective against T. evansi isolates in Saudi Arabia. In addition to being effective in clearing parasitemia in mice, the drug also did not have any detectable toxic effects. The present study also supports the findings of Gillingwater et al. (2007) that suramin is effective against several stocks of T. evansi from Brazil, Columbia, Kazakhstan, Philippines, Indonesia, Kenya, China and Vietnam. Nevertheless, the drug is no longer available in the market (Desquesnes et al. 2013).
Relapse of parasitemia in mice (C4 on days 29 and A9 on days 31) treated with diminazene aceturate at a dose of $7 \mathrm{mg} \mathrm{kg}^{-1}$, indicates that this drug is no longer effective in treating the infection with some of the $T$. evansi isolates in Mindanao. This is in line with the result of a previous study with Ethiopian T. evansi type A and type B treated with diminazene aceturate + antypirine (DIM) and diminazene aceturate + phenazone granules (DIM-SEQ) wherein more than half of the $T$. evansi-infected mice relapsed on the $4^{\text {th }}$ week post-treatment (Mekonnen et al. 2018). Interestingly, water buffaloes experimentally infected with $T$. evansi in Mindanao were not also cured by diminazene (Dargantes et al. in preparation). Kabi et al. (2009) also reported that diminazene aceturate is no longer suitable for the treatment of surra amongst camels in Uganda.

The most likely explanation of this result in the present study is that the two relapsing isolates had a degree of resistance to diminazene aceturate whereas the other isolates tested are susceptible. Nevertheless, it cannot be deduced as to what extent resistance is likely to be demonstrated in domestic animals, causing 
treatment to be ineffective. This is because the isolates of $T$. evansi screened in the present study were not random selection of $T$. evansi strains in Mindanao and the comparative plasma levels and pharmacokinetics of diminazene aceturate in mice dosed at $7 \mathrm{mg} \mathrm{kg}^{-1}$ with those achieved in domestic animals dosed at $3.5 \mathrm{mg} \mathrm{kg}^{-1}$ are unknown. However, the use of diminazene aceturate for treatment of surra among animals in Mindanao should be discontinued to prevent further development of resistance among $T$. evansi isolates on the island.

Another possible explanation for the relapsing $T$. evansi infection in mice as observed in this study was the failure of diminazene to reach trypanosomes invading reserved tissues particularly the brain (AlMohammed 2008; Jatau et al. 2010). Relapsing parasitemia was also observed in mice infected with tissue-invading $T$. brucei and T. vivax and treated with diminazene aceturate (Qadeer et al. 2013).

Diminazene has been widely used in Mindanao for more than two decades at the recommended dose rate of $3.5 \mathrm{mg} \mathrm{kg}$-1 bodyweight. It is widely accepted that prolonged usage of the same drug, especially at subtherapeutic doses, leads to drug resistance which may also be aggravated by immunosuppression. Animals may be underdosed in the field where bodyweights are often estimated roughly, with the consequence that the computed dose is usually below the recommended therapeutic dose. Immunosuppression may be induced by heavy parasite burden, stressful conditions or trypanosomiasis (Yayeh et al. 2018). Drug resistance of trypanosomes to diminazene aceturate is common in African and Asian countries. Evidence of resistance was also provided in in vitro and in vivo trials with isolates collected from China, Ethiopia and the Philippines (Zhou et al. 2004; Nuryady et al. 2019).

\section{CONCLUSION}

It is concluded that the $T$. evansi isolates from Mindanao, Philippines, tested in this study, are more pathogenic than the isolate from East Java, Indonesia, with minimal pathogenic heterogeneity among the Philippine T. evansi isolates. Quinapyramine sulphate/chloride, melarsomine dihydrochloride and suramin are effective against the $T$. evansi isolates tested while the use of diminazene against surra in Mindanao should be re-evaluated. This information is valuable in the enhancement of the control strategy against surra in the Philippines and Indonesia.

\section{ACKNOWLEDGEMENT}

Dargantes AP and Wardhana AH are equal authors in the manuscript production. The authors would like to thank Dr. R. Mercado, Dr. L.T. Simborio, Dr. J.
Elevazo, Dr. J. Dargantes and J. Gamboa for their invaluable help; Dr. E. Lim, Dr. E. Igsoc, Dr. P. Calo, Dr. M. Samar, staff of Mindanao Unified Surra Control Approach (MUSCA), Regional Disease Diagnostic Laboratories (RDDL) of Regions XI and Caraga, and Provincial Veterinary Offices (PVO) of Agusan del Sur and South Cotabato for their assistance during the collection of samples; Dr. P.K. Sanyal for the supply of Triquin $^{\circledR}$; M. Palaca for technical help; and, the Australian Institute for Tropical Veterinary and Animal Science (AITVAS), Australian Centre for International Agricultural Research (ACIAR), Australian Agency for International Development (AusAID), International Foundation of Science (IFS) and Central Mindanao University (CMU) for the financial support.

\section{REFERENCES}

Al-Mohammed HI. 2008. Comparative in vivo activities of diminazene, suramine, quinapyramine and homidium bromide on Trypanosoma evansi infection in mice. Sci J King Faisal Univ. 9:139-147.

Begolo D, Vincent IM, Giordani F, Pöhner I, Witty MJ, Rowan TG, Bengaly Z, Gillingwater K, Freund Y, Wade RC, et al. 2018. The trypanocidal benzoxaborole AN7973 inhibits trypanosome mRNA processing. Phillips MA, editor. PLOS Pathog. 14:e1007315.

Bengaly Z, Sidibe I, Boly H, Sawadogo L, Desquesnes M. 2002. Comparative pathogenicity of three genetically distinct Trypanosoma congolense-types in inbred Balb/c mice. Vet Parasitol. 105:111-118.

Boushaki D, Adel A, Dia ML, Büscher P, Madani H, Brihoum BA, Sadaoui H, Bouayed N, Kechemir Issad N. 2019. Epidemiological investigations on Trypanosoma evansi infection in dromedary camels in the South of Algeria. Heliyon. 5:e02086.

Chau NVV, Chau LB, Desquesnes M, Herder S, Lan NPH, Campbell JI, Cuong N Van, Yimming B, Chalermwong P, Jittapalapong S, Franco JR, Tue NT, Rabaa MA, Carrique-Mas J, Thanh TPT, Thieu NTV, Berto V, Hoa NT, Hoang NVM, Tu NC, Chuyen NK, Wills B, Hien TT, Thwaites GE, Yacoub S, Baker S. 2016. A clinical and epidemiological investigation of the first reported human infection with the zoonotic parasite Trypanosoma evansi in Southeast Asia. Clin Infect Dis. 62:1002-1008.

Dargantes AP, Mercado RT, Dobson RJ, Reid SA. 2009. Estimating the impact of Trypanosoma evansi infection (surra) on buffalo population dynamics in southern Philippines using data from cross-sectional surveys. Int J Parasitol. 39:1109-1114.

Desquesnes M, Dargantes A, Lai DH, Lun ZR, Holzmuller P, Jittapalapong S. 2013. Trypanosoma evansi and surra: A review and perspectives on transmission, epidemiology and control, impact, and zoonotic aspects. Biomed Res Int. 2013: 1-20. 
Dewi RS, Damajanti R, Wardhana AH, Mulatsih S, Poetri ON, Steeneveld W, Hogeveen H. 2020. The economic losses of surra outbreak in Sumba Timur, Nusa Tenggara Timur-Indonesia. Trop Anim Sci J. 43:77-85.

Dewi RS, Wardhana AH, Soejoedono RD, Mulatsih S. 2019. Evaluation of surra treatment strategies attacking horses and buffaloes in East Sumba District, Nusa Tenggara Timur Province of Indonesia $(2010$ - 2016). JITV. 24:39-48.

Dobson RJ, Dargantes AP, Mercado RT, Reid SA. 2009. Models for Trypanosoma evansi (surra), its control and economic impact on small-hold livestock owners in the Philippines. Int J Parasitol. 39:1115-1123.

Garba U, Sackey A, Lawal A, Esievo K, Bisalla M, Sambo J. 2017. Gross and histopathological alterations in experimental Trypanosoma evansi infection in Donkeys and the effect of isometamidium chloride treatment. J Vet Sci Anim Husb. 5:1-10.

Gillingwater K. 2018. In vitro and in vivo efficacy of diamidines against Trypanosoma equiperdum strains. Parasitology. 145:953-960.

Gillingwater K, Büscher P, Brun R. 2007. Establishment of a panel of reference Trypanosoma evansi and Trypanosoma equiperdum strains for drug screening. Vet Parasitol. 148:114-121.

Gillingwater K, Kumar A, Anbazhagan M, Boykin DW, Tidwell RR, Brun R. 2009. In vivo investigations of selected diamidine compounds against Trypanosoma evansi using a mouse model. Antimicrob Agents Chemother. 53:5074-5079.

Giordani F, Morrison LJ, Rowan TG, De Koning HP, Barrett MP. 2016. The animal trypanosomiases and their chemotherapy: a review. Parasitology. 143:1862-1889.

Gressler L, Oliveira C, Coradini K, Rosa L, Grando T, Baldissera M, Zimmermann C, Da-Silva A, Almedia T, Hermes C, et al. 2015. Trypanocidal activity of free and nanoencapsulated curcumin on Trypanosoma evansi. Parasitology. 142:439-448.

Hébert L, Guitton E, Madeline A, Géraud T, Zientara S, Laugier C, Hans A, Büscher P, Cauchard J, Petry S. 2018. Melarsomine hydrochloride (Cymelarsan $\left.{ }^{\circledR}\right)$ fails to cure horses with Trypanosoma equiperdum OVI parasites in their cerebrospinal fluid. Vet Parasitol. 264:47-51

Holzmuller P, Biron DG, Courtois P, Koffi M, BrasGonçalves R, Daulouède S, Solano P, Cuny G, Vincendeau P, Jamonneau V. 2008. Virulence and pathogenicity patterns of Trypanosoma brucei gambiense field isolates in experimentally infected mouse: differences in host immune response modulation by secretome and proteomics. Microbes Infect. 10:7986.

Jatau I, Lawal, AI, Agbede R, Abdurrahman E. 2010. Efficacies of diminazene acetururate and isometamidium chloride in Trypanosoma evansi experimentally infected rats. Sokoto J Vet Sci. 8:4-8.
Kabi F, Waiswa C, Olaho-Mukani W, Walubengo J. 2009. Comparative in vivo drug sensitivity study of Trypanosoma evansi isolates from Moroto, Uganda to Trypan $^{\circledR}$, Triquin- $S^{\circledR}$ and Cymelarsan ${ }^{\circledR}$. Africa J Anim Biomed Sci. 4:36-42.

Kamidi CM, Auma J, Mireji PO, Ndungu K, Bateta R, Kurgat R, Ouma C, Aksoy S, Murilla G. 2018. Differential virulence of camel Trypanosoma evansi isolates in mice. Parasitology. 145:1235-1242.

Lazaro JEH, Bascos NAD, Tablizo FA, Abes NS, Paynaganan RID, Miguel MA, Espiritu HM, Uy MRD, Mingala CN, Saloma CP. 2019. Genome-wide analysis for variants in Philippine Trypanosoma evansi isolates with varying drug resistance profiles. Philipp J Sci. 148 (SI):219233.

Macaraeg BB, Lazaro J V, Abes NS, Mingala CN. 2013. In vivo assessment of the effect of trypanocidal drugs againts Trypanosoma evansi isolates from Phillippine water buffaloes (Bubalus bubalis). Vet Arkhiv. 83:381392.

McInnes LM, Dargantes AP, Ryan UM, Reid SA. 2012. Microsatellite typing and population structuring of Trypanosoma evansi in Mindanao, Philippines. Vet Parasitol. 187:129-139.

Mekata H, Konnai S, Mingala CN, Abes NS, Gutierrez CA, Dargantes AP, Witola WH, Inoue N, Onuma M, Murata S, Ohashi K. 2013. Isolation, cloning, and pathologic analysis of Trypanosoma evansi field isolates. Parasitol Res. 112:1513-1521.

Mekonnen G, Mohammed EF, Kidane W, Nesibu A, Yohannes H, Van Reet N, Büscher P, Birhanu H. 2018. Isometamidium chloride and homidium chloride fail to cure mice infected with Ethiopian Trypanosoma evansi type A and B. Raper J, editor. PLoS Negl Trop Dis. 12:e0006790.

Nuryady MM, Widayanti R, Nurcahyo RW, Fadjrinatha B, Fahrurrozi AZS. 2019. Characterization and phylogenetic analysis of multidrug-resistant proteinencoding genes in Trypanosoma evansi isolated from buffaloes in Ngawi district, Indonesia. Vet World. 12:1573-1577.

Parreira DR, Jansen AM, Abreu UGP, Macedo GC, Silva ARS, Mazur C, Andrade GB, Herrera HM. 2016. Health and epidemiological approaches of Trypanosoma evansi and equine infectious anemia virus in naturally infected horses at southern Pantanal. Acta Trop. 163:98-102.

Perrone T, Aso P, Mijares A, Holzmuller P, Gonzatti M, Parra N. 2018. Comparison of infectivity and virulence of clones of Trypanosoma evansi and Trypanosoma equiperdum Venezuelan strains in mice. Vet Parasitol. 253:60-64.

Qadeer M, Aamu T, Gumel M, Nganjiwa J. 2013. Sensitivity of bovine Trypanosoma vivax isolate using three trypanocidal drugs in experimentally induced caprine trypanosomosis. Int J Sci Res. 4:2343-2352. 
Queiroz AO, Cabello PH, Jansen AM. 2000. Biological and biochemical characterization of isolates of Trypanosoma evansi from Pantanal of Matogrosso Brazil. Vet Parasitol. 92:107-118.

Ramirez-Barrios R, Reyna-Bello A, Parra O, Valeris R, Tavares-Marques L, Brizard J-P, Demettre E, Seveno M, Martinez-Moreno A, Holzmuller P. 2019. Trypanosoma vivax infection in sheep: Different patterns of virulence and pathogenicity associated with differentially expressed proteomes. Vet Parasitol X. 2:100014.

Sawitri DH, Wardhana AH. 2017. Genetic variability of ESAG6/7 gene Trypanosoma evansi. JITV. 22:38-50.

Sawitri DH, Wardhana AH, Sadikin M, Wibowo H. 2019. Detection of Surra (trypanosomiasis) positivity in humans in an outbreak area of Indonesia. Med J Indones. 28:196-202.

Shiferaw S, Muktar Y, Belina D. 2015. A review on trypanocidal drug resistance in Ethiopia. J Parasitol Vector Biol. 7:58-66.
Verdillo JCM, Lazaro J V., Abes NS, Mingala CN. 2012. Comparative virulence of three Trypanosoma evansi isolates from water buffaloes in the Philippines. Exp Parasitol. 130:130-134.

Villareal M, Mingala C, Rivera W. 2013. Molecular characterization of Trypanosoma evansi isolates from water buffaloes (Bubalus bubalis) in the Philippines. Acta Parasitol. 58:6-12.

Wardhana A, Sawitri H. 2018. Surra: Trypanosomiasis pada ternak yang berpotensi sebagai penyakit zoonosis. Wartazoa. 28:139-151.

Yayeh M, Dagnachew S, Tilahun M, Melaku A, Mitiku T, Yesuf M, Seyoum Z, Kefyalew H. 2018. Comparative experimental studies on Trypanosoma isolates in mice and response to diminazene aceturate and isometamidium chloride treatment. Heliyon. 4:e00528.

Zhou J, Shen J, Liao D, Zhou Y, Lin J. 2004. Resistance to drug by different isolates Trypanosoma evansi in China. Acta Trop. 90:271-275. 